\title{
ESTIMATION OF THE OPTIMUM INTERVAL BETWEEN INSEMINATION AND OVULATION IN THE RABBIT BY DOUBLE INSEMINATION
}

\author{
O. C. MILlER, J. F. ROGHE* AND P. J. DZIUK* ${ }^{*}$ \\ Departments of Dairy Science and *Animal Science, University of Illinois, \\ Urbana, Illinois 61801, U.S.A.
}

(Received 28th October 1968)

Rabbit spermatozoa do not attain fertilizing ability until several hours after deposition in the female genital tract but, equally, they do have a finite life. Rabbit spermatozoa aged in vitro for $24 \mathrm{hr}$ fertilized only $5 \%$ of eggs in competition with equal numbers of fresh spermatozoa (Roche, Dziuk \& Lodge, 1968). When does were double-mated, the first buck sired $86 \%$ of offspring when the interval between the first mating and ovulation was $10 \mathrm{hr}$ or less (Dziuk, 1965). This showed that spermatozoa that have spent $10 \mathrm{hr}$ in the female genital tract have an advantage in fertilizing ability compared to those which spent less time there.

The following experiment was conducted to determine whether or not the first male would maintain this advantage as the interval between the first insemination and ovulation was increased beyond $10 \mathrm{hr}$.

Semen was collected from New Zealand White (W) and Dutch Belted (B) bucks with an artificial vagina. Genetic homozygosity was established by periodic non-experimental inseminations. Each $W$ female was inseminated within 45 min of collection with $20 \times 10^{6}$ motile spermatozoa from either a B or $\mathrm{W}$ male in $0.3 \mathrm{ml}$ of $2.9 \%$ sodium citrate in distilled water. Three hours later, the doe was re-inseminated with spermatozoa from the male of opposite colour. The interval between the first insemination and ovulation was 19, 16, 13 or $10 \mathrm{hr}$. Ovulation was induced by an intravenous injection of 50 i.u. of human chorionic gonadotrophin at the appropriate time. It was assumed that insemination does not by itself induce ovulation (Hammond \& Asdell, 1926). The paternity of the offspring was established by frequent examinations of young following delivery from the fifty-eight pregnant does.

A summary of the results is shown in Table 1. The first buck had a distinct advantage (sired $73 \%$ of offspring) over the second, when mated $10 \mathrm{hr}$ before ovulation. As the interval between the first buck and ovulation increased from 13 to $16 \mathrm{hr}$ and finally to $19 \mathrm{hr}$, the proportion of offspring from the first buck was reduced from $54 \%$ to $39 \%$ and finally to $18 \%$. Litter size varied considerably among does but was not different among groups. There were twentynine litters from does inseminated first with spermatozoa from a $W$ buck and twenty-nine litters when a B buck was mated first. The B and W bucks were

$\uparrow$ Present address: Animal Genetics, University of Illinois, Urbana, Illinois 61801, U.S.A. 
mated first with almost equal frequency in each of the four intervals before ovulation. There were $247 \mathrm{~W}$ and $168 \mathrm{~B}$ offspring. The first buck sired 209, and the second sired 206 offspring.

The observation that the first buck has an advantage and sired a larger proportion of the offspring $(73 \%)$ when mated $10 \mathrm{hr}$ before ovulation substantiates the previous observation using a similar régime (Dziuk, 1965). As the interval from insemination to ovulation increased, the proportion of offspring from the first buck decreased to $18 \%$, indicating that intervals greater than 10 to $13 \mathrm{hr}$ are disadvantageous. On the basis of these two observations, it appears that rabbit spermatozoa fertilize eggs more readily when they have spent 10 to $13 \mathrm{hr}$ in the female reproductive tract than when they have spent either more or less time there. The optimum time for insemination would thus appear to be 10 to $13 \mathrm{hr}$ before ovulation. The rabbit is an induced ovulator, ovulation occurring 10 to $12 \mathrm{hr}$ after mating. From an evolutionary stand-

TABLE 1

PROPORTION OF OFFSPRING SIRED BY FIRST MALE FROM DOES INSEMINATED TWICE

\begin{tabular}{c|c|c|c|c|c}
\hline \multicolumn{2}{c|}{$\begin{array}{c}\text { Interval between insemination and } \\
\text { ovulation }\end{array}$} & & \multicolumn{2}{|c}{$\begin{array}{c}\text { Offsping from first } \\
\text { male }\end{array}$} \\
\cline { 1 - 2 } $\begin{array}{c}\text { First insemination } \\
(\text { hr })\end{array}$ & $\begin{array}{c}\text { Second insemination } \\
(\text { hr })\end{array}$ & $\begin{array}{c}\text { No. of } \\
\text { litters }\end{array}$ & $\begin{array}{c}\text { No. of } \\
\text { offspring }\end{array}$ & No. & $\%$ \\
\hline 19 & 16 & 9 & 51 & 9 & 18 \\
16 & 13 & 16 & 117 & 46 & 39 \\
13 & 10 & 17 & 138 & 74 & 54 \\
10 & 7 & 16 & 109 & 80 & 73 \\
\hline Total & & 58 & 415 & 209 & 50 \\
\hline
\end{tabular}

point, those females ovulating 10 to $13 \mathrm{hr}$ after mating would appear to have a selective advantage because spermatozoa were best able to fertilize eggs after this interval. Equally, bucks whose spermatozoa reached optimum fertilizing ability 10 to $13 \mathrm{hr}$ after mating would have an advantage over others if the mating-to-ovulation interval were genetically inflexible.

The spermatozoa from $\mathrm{W}$ bucks apparently have some advantage over $\mathbf{B}$ spermatozoa because they fertilized a greater proportion of eggs than B spermatozoa in reciprocal double matings. This innate advantage of one male over another has been noted previously by Beatty (1960).

\section{REFERENCES}

BeAtTy, R. A. (1960) Fertility of mixed semen from different rabbits. F. Reprod. Fert. 1, 52.

Dzruk, P. J. (1965) Double mating of rabbits to determine capacitation time. F. Reprod. Fert. 10, 389.

Hammond, J. \& AsDele, S. A. (1926) The vitality of spermatozoa in male and female reproductive tracts. Br. F. exp. Biol. 4, 155.

Roche, J. F., DziUx, P. J. \& LoDge, J. R. (1968) Competition between fresh and aged spermatozoa in fertilizing rabbit eggs. F. Reprod. Fert. 16, 155. 